Click www.researchjournal.co.in/online/subdetail.html to purchase.

Volume 5 | Issue 2 | September, 2014 | 241-244 @ e ISSN-2231-6434 |

International Research Journal of Agricultural Economics and Statistics

Visit Us - www.researchjournal.co.in DOI : 10.15740/HAS/RJAES/5.2/241-244

\title{
Research Paper A study of integration of markets for onion and potato in South Gujarat
}

NARENDRA SINGH

ABSTRACT : This study investigates the level of market integration in the South Gujarat onion and potato markets. The results indicated that the correlation co-efficients in monthly wholesale prices for onion and potato between all the selected market pairs were positive and significantly different from zero. The onion and potato prices in these markets were interdependent to the corresponding market. The results of the study show that there is strong market integration among selected market pairs which can be due to movement of produce from one market to another market. Therefore, in order to continue the competitive condition of these markets there is need to strengthen the market intelligence and communication within markets which would provide a better platform for guiding the farmers in marketing their produce.

KEY WORDS : Market integration, Competitive, Wholesale market

HOW TO CITE THIS PAPER : Singh, Narendra (2014). A study of integration of markets for onion and potato in South Gujarat. Internat. Res. J. Agric. Eco. \& Stat., 5(2) : 241-244. 